Zainicjowany temat dotyczacy współczesnego szkolnictwa i oświaty w okresie transformacji jest efektem powstania wstępnych zespołów, które maja w najbliższym czasie rozpoczać pracę nad ta problematyka.

Konferencję uzupełnila wycieczka krajoznawcza, która pozwoliła uczestnikom spotkania podziwiaદ przepiękne krajobrazy Kotliny Klodzkiej.

Organizatorzy konferencji zapowiedzieli publikację referatów.

Justyna Gulczyńska

\title{
Pierwsze Walne Zebranie Towarzystwa Historii Edukacji
}

W dniu 26 czerwca 2001 roku odbyło się w sali konferencyjnej Wydziału Pedagogicznego Uniwersytetu Warszawskiego I Walne Zebranie Towarzystwa Historii Edukacji. W Zebraniu tym (zorganizowanym przez Komitet Założycielski THE, utworzony jeszcze na poczatku 2000 roku) uczestniczyli przedstawiciele większości krajowych ośrodków badawczych w dziedzinie historii wychowania.

Spotkanic otworzył prof. Józef Miaso. W swoim wystapieniu podkreślił znaczenie odbywającego się Zebrania oraz rolę Towarzystwa w organizowaniu życia naukowego polskich historyków wychowania. Na przewodniczacego I Walnego Zebrania THE wybrano prof. Czesława Majorka. Podczas dyskusji wskazywano na niezbędne korekty w Statucie Towarzystwa, jak również na podstawowe kierunki prac nowopowołanego stowarzyszenia. Wiele miejsca zajęła również sprawa organizowania - pod auspicjami Towarzystwa Historii Edukacji i Katedry Historii Oswiaty i Wychowania Akademii Pedagogicznej w Krakowie - dorocznego ogólnopolskiego konkursu na prace magisterskie z historii edukacji.

Podczas I Walnego Zebrania dokonano także wyboru pierwszych wladz Towarzystwa. Funkcje prezesa powierzono jednogłośnie prof. Irenie Szybiak. Wiceprezesami zostali natomiast prof. Dorota Żłądź-Strzelczyk i prof. Julian Dybiec. Do Zarządu Głównego, na najbliższą czteroletnia kadencję, weszli ponadto: prof. Krzysztof Jakubiak (skarbnik), dr Adam Fijałkowski (sekretarz), prof. Kalina Bartnicka (członek) i prof. Andrzej Meissner (członek). Funkcję przewodniczacego Komisji Rewizyjnej powierzono prof. Lechowi Mokrzeckiemu, a stanowisko przewodniczącego Sądu Koleżeńskiego prof. Stanisławowi Litakowi.

Wiestaw Jamrozek

\section{Zapowiedzi}

Łódź, 22 - 23 października 2001 r. - Międzynarodowa konferencja naukowa nt. „Szkolnictwo niepubliczne w Europie i w Polsce w XX wieku (przeszłość - teraźniejszość - przyszłośc)"

Organizatorem konferencji jest Katedra Historii Wychowania i Pedeutologii Uniwersytetu Łódzkiego. Celem - przegląd rozwiązań organizacyjnych, podstaw prawnych i merytorycznych działalności szkolnictwa niepublicznego różnych stopni w przeszłości oraz próba określenia perspektyw jego rozwoju. 


\section{Kraków 17-18 stycznia 2002 - Ogólnopolska konferencja naukowa}

Dziekan i Rada Wydziału Pedagogicznego Akademii Pedagogicznej w Krakowie organizuja ogólnopolską konferencję nt. „Nauki pedagogiczne - ich rozwój i wkład w przemiany edukacyjne”. Organizatorzy proponują następująca tematykę:

1. Miejsce nauk psychologicznych w edukacji nauczycieli

2. Znaczenie integracji i zintegrowanego nauczania dla rozwoju dziecka i efektywności edukacji

3. Dziecko we współczesnych badaniach psychologicznych i pedagogicznych

4. Historia przemian edukacyjnych

5. Wychowanic przez sztukę i dla sztuki

6. Edukacja w dobie rewolucji informatycznej

7. Pedagogika w wychowaniu dla demokracji

8. Kompetencje nauczyciela

9. Miejsce nauk pedagogicznych i psychologicznych w dobie zagrożeń cywilizacyjnych. 